\title{
PROSPECTS FOR USE OF AEROSPACE MONITORING FOR ACCELERATED DEVELOPMENT OF LIVESTOCK GRAZING
}

\author{
Vladimir Trukhachev, Sergei Oliinyk, Tatyana Lesnyak, Irina Kartavtseva \\ Stavropol State Agrarian University, Russia \\ rector@stgau.ru,soliynik60@gmail.com, tatastav026@gmail.com, irina.pigareva@mail.ru
}

\begin{abstract}
The development of an innovative system of livestock grazing based on the use of the digital aerospace technology and telemetry is a new modern direction of development of the livestock industry. It is designed to solve the numerous problems of restoring soil fertility and pastures for animals. To develop a methodology for distant assessment of pastureland fertility, technological capabilities of unmanned aerial vehicles (UAV) and satellite service were used. It allows studying the dynamics of the NDVI (Normalized Difference Vegetation Index) of various pasture plots in the Stavropol Territory of the Russian Federation. The analysis of literary sources shows that the main problems associated with the complex automation of complex objects forecasting processes are not technical, but methodological in nature and are caused by the lack of a theoretical framework that should be used as the basis for creating the appropriate model-algorithmic support. Comparison of the results of the prognostic evaluation of the nutritional value of forage plants obtained from UAV images and space services with the actual nutritional values obtained from the study of the zoochemical composition of feed showed a high degree of correlation in the range of 0.65-0.75. It was recognized that application of the capabilities of UAVs to assess the ethological features of sheep of the Manych Merino breed is promising. It allows optimizing the acquisition of groups of animals consolidated in feeding activity.
\end{abstract}

Key words: livestock grazing, aerospace monitoring, sheep, Manych Merino, vegetation index.

\section{Introduction}

Sheep grazing is one of the most common livestock industries in southern Russia and plays an important role in saturating the domestic market with high-quality lamb obtained from fine-fleece and wool breeds. One of that is the new breed Manych Merino. This breed is fine-fleece and meat-wool. It was bred in the Stavropol Region by cross-over of two sheep breeds -the Stavropol and Australian Merino. Animals of the new genotype have a strong constitution. They are compact. Their torso is proportional. The live weight of adult queens is $50-55 \mathrm{~kg}$, with hair cut up to 4 kilograms. Live weight of the sheep can reach $109-115 \mathrm{~kg}$ with hair cut up to $7.8 \mathrm{~kg}$. Sheep of the new breed have good adaptive and reproductive qualities in the arid climate of Stavropol. Thus, the yield of lambs per 100 queens, on average, is $110-115$ heads $[1 ; 2]$.

The climatic conditions of the farming region of Manych Merino sheep are characterized as sharply continental. The amplitude of fluctuations of maximum and minimum air temperatures reaches $+42{ }^{\circ} \mathrm{C}$ in summer and $-34{ }^{\circ} \mathrm{C}$ in winter. The average annual precipitation is, on average, 320$412 \mathrm{~mm}$. In summertime, the east wind brings the hot air of the Central Asian deserts. It is associated with droughts and dust storms, the speed of which can be $15-20 \mathrm{~m} \cdot \mathrm{s}^{-1}$. Droughts and dry winds of varying intensity are typical for this region. Summer has 85-100 days with dry winds. $44 \%$ of the total areas are spring and autumn pastures, $46 \%$ are winter pastures, only $10 \%$ are summer pastures. Significant number of farms in the desert and foothill areas at a hot period of time distills the cattle for 80-90 days on summer pastures, which are situated 150-200 km away. In such extreme climatic conditions, it is especially important for successful management of sheep grazing to organize rational use of pasture areas. The distance between them takes tens or hundreds of kilometers. The development of distant aerospace monitoring methods can give a new positive impetus for the development of such an ancient type of animal husbandry as sheep grazing. In this regard, the study of the possibility of combining various distant aerospace monitoring methods for effective management of this agricultural featureis of concern [3;4].

\section{Materials and research methods}

The studies were conducted in the Stavropol Territory of the Russian Federation under the production conditions of a specialized farm for growing the Manych Merino breed. The animals were on summer pastures from April to August. The stocking of the pasture was 10 heads on 1 ha. Evaluation of development indicators of 3-months-oldgrowing replacement young animals was carried 
out in the period April-August by assessing the development of the animals in the control group, $n=20$. The live weight was taken into account. The average daily weight gain was calculated.

Pasture feed for the research was selected during the main growing season of plants (June-July) and studied by standard generally accepted methods. Crude protein of feed was determined by ashing of the organic matter of the analyzed sample with sulfuric acid in the presence of a catalyst, alkalizing of the reaction product, distilling and titrating of the released ammonia according to the Kjeldahl's method. Crude fiber was determined with the method of Genneberg and Shtoman by sequential processing of the test sample weight with solutions of acid and alkali, ashing and quantitative determination of organic residue by the gravimetric method. The content of crude fiber is measured as a mass fraction in $\%$ or in grams per $1 \mathrm{~kg}$ of dry matter. Crude fat in the feed was determined by the method of extraction of crude fat from a sample of diethyl or petroleum ether in a Soxhlet apparatus, while removing the solvent and weighing the fat-free residue. Crude ash in the feed was determined by determination of the mass of the residue after combustion and subsequent calcination of the sample. Calcium in the feed was determined by the ashing method of the organic substances of the analyzed sample, precipitating calcium in the form of calcium oxalate with titration with potassium permanganate. Phosphorus in the feed was determined by dry ashing of the sample with calcium carbonate and heating of the residue with hydrochloric and nitric acids (for organic feed). The aliquot of the hydrolysate was mixed with the molybdovanadate reagent and the optical density of the solution was measured at $430 \mathrm{~nm}$.

For aerospace monitoring, unmanned aerial vehicles (UAVs) of the middle class with a take-off weight from 100 to $300 \mathrm{~kg}$ and a range of action from 150 to $1000 \mathrm{~km}$ were used. In addition to the main equipment, the onboard equipment of the UAV payload also included a digital camera and an infra-red camera. They enable to calculate the NDVI. Optic and electronic means of the UAVs were used to review the territory; obtaining a detailed image of areas and objects located on them; detection and recognition of objects, which are situated on the ground and visually invisible. The technical equipment was placed on the UAV using gyro-stabilized platforms that ensure rotation of the optical axes of the devices to any direction with a given speed.

To create a detailed digital map of the area and the location of pastures, they produced aerial photography. The initial parameters for photographing with the help of UAVs were the required image resolution, camera resolution, camera lens angle of view and the frame overlap value. According to these data, the flight altitude, the speed of the vehicle and the shutter frequency of the camera were calculated.

The resolution of the aerial photography was calculated by the formula:

$$
R=\frac{h H}{f s}(\mathrm{MP})
$$

where $h$-height (width) of camera sensor, mm;

$H$ - flight altitude of UAV above the ground, m;

$f$ - camera focus, $\mathrm{mm}$;

$s$ - height (width) of photo (pixels).

The centers of photographing area of aerial photography and the route of flight were calculated on the base of the geographical nodes of the pasture contour. The payload was controlled in real time by software from the automated workplace of the UAV operator and the payload operator in accordance with the flight task. The results of the work of the payload were transmitted from the UAV via a highspeed simplex communication channel to the ground control station and stored on a memory card in the UAV board. The UAV automatically calculates its speed and shutter frequency (frame rate) during the flight so as to provide the specified frame overlap.The pictures from UAVs are usually overlapped by $80 \%$ in the longitudinal overlap and by $60 \%$ in the transverse overlap (the degree of overlap is determined by the territory and the type of area). As a result of the flight, a set of photographs and telemetry data are formed - exterior orientation parameters fixed in flight (linear - Xs, Ys, Zs coordinates of the photographing center; angular $-\alpha, \beta, \gamma-$ camera orientation relative to the coordinate axes) $[5 ; 6]$. 
An array of geolocated photographs is reduced to one geotagged raster image, a 3D model of the area is built (digital elevation map). Using the automated decoding and vectorization complex, the updated contours and areas of fields are calculated. According to the results of aerial photography of the area by a modified camera, the NDVI map is calculated using a single geolocated image.

Based on the results of using satellite services, panchromatic, color and multispectral images of the Earth's surface were studied using the automated interpretation and the vectorization complex. On the base of the obtained results, the NDVI of the selected pasture area was studied $[7 ; 8]$.

\section{Research results and discussion}

The botanical composition and its yield of plant biomass of the pasture area during the production period are presented in Table 1 .

\section{Dynamics of botanical composition and biological productivity of a pasture during the production period}

\begin{tabular}{|c|c|c|}
\hline \multirow{2}{*}{ Indicators } & \multicolumn{2}{|c|}{ Rolling months } \\
\cline { 2 - 3 } & April & August \\
\hline Cereals & 80.0 & 85.0 \\
\hline Legume grasses & 15.0 & 10.0 \\
\hline Herbs & 5.0 & 5.0 \\
\hline Harmful plants & - & - \\
\hline Noxious plants & - & - \\
\hline${\text { Yield, } \mathrm{t} \cdot \mathrm{ha}^{-1}}^{-1}$ & 3.3 & 1.7 \\
\hline
\end{tabular}

The structure of the botanical composition of the grazing land is dominated by cereals. They make $80-85 \%$ of the total mass.

In the process of plant vegetation the content of protein decreases, carotene and fiber content increases. It results in digestibility and energy value decrease. The data are presented in Table 2.

Dynamics of the chemical composition of green feed during the growing season, $\%$

\begin{tabular}{|c|c|c|c|c|c|c|c|}
\hline Grass plant & \begin{tabular}{|c|}
$\begin{array}{c}\text { Vegetative } \\
\text { stage }\end{array}$ \\
\end{tabular} & $\begin{array}{c}\text { Dry } \\
\text { basis }\end{array}$ & Protein & Fat & Fiber & $\begin{array}{l}\text { Nitrogen-freeextr } \\
\text { active substances }\end{array}$ & Ash \\
\hline \multirow{3}{*}{ Bromopsisinermis } & Booting & 24.30 & 4.49 & 0.83 & 6.16 & 10.59 & 2.23 \\
\hline & Heading & 26.62 & 3.92 & 0.65 & 7.89 & 12.00 & 2.16 \\
\hline & Flowering & 28.11 & 2.92 & 0.60 & 8.66 & 13.97 & 1.96 \\
\hline \multirow{3}{*}{ Festucapratensis } & Booting & 26.49 & 3.60 & 0.83 & 6.22 & 13.48 & 2.36 \\
\hline & Heading & 26.95 & 3.03 & 0.71 & 8.31 & 13.13 & 1.77 \\
\hline & Flowering & 28.72 & 2.37 & 0.69 & 9.22 & 14.75 & 1.69 \\
\hline \multirow{3}{*}{ Trifoliumrubens } & Booting & 17.73 & 3.81 & 0.51 & 4.24 & 7.11 & 2.06 \\
\hline & Heading & 18.73 & 3.22 & 0.83 & 4.65 & 8.35 & 1.68 \\
\hline & Flowering & 23.73 & 3.00 & 0.56 & 6.96 & 11.45 & 1.54 \\
\hline \multirow{3}{*}{ Poapraténsis } & Booting & 27.96 & 3.55 & 0.56 & 7.22 & 14.21 & 2.42 \\
\hline & Heading & 31.91 & 3.06 & 0.63 & 9.00 & 17.02 & 2.20 \\
\hline & Flowering & 38.92 & 3.04 & 0.82 & 11.70 & 19.98 & 3.38 \\
\hline \multirow{3}{*}{ Dactylisglomerata } & Booting & 21.54 & 3.52 & 0.56 & 5.26 & 10.26 & 1.94 \\
\hline & Heading & 23.43 & 3.07 & 0.70 & 5.86 & 11.92 & 1.88 \\
\hline & Flowering & 28.49 & 2.90 & 0.84 & 9.50 & 12.96 & 2.30 \\
\hline \multirow[t]{3}{*}{ Melilotusalbus } & Booting & 19.00 & 3.98 & 0.89 & 4.40 & 8.01 & 1.72 \\
\hline & Heading & 20.77 & 3.30 & 0.85 & 5.81 & 9.36 & 1.46 \\
\hline & Flowering & 24.15 & 3.24 & 0.77 & 7.87 & 10.33 & 1.94 \\
\hline
\end{tabular}

Bromopsisinermis and Poapraténsis in all phases of the growing season contain protein, the most deficient nutrient, in the feed balance more than other grains. Dactylisglomerata is rich with protein, 
too. If we consider that it is drought-resistant, it starts moving up early in the spring and is well eaten by animals, it is possible to recommend it for development of artificial pastures. Poapraténsis and Festucapratensis contain more nitrogen-free extractive substances than Bromopsisinermis and Dactylisglomerata. Melilotusalbus has the highest level of protein among legume grasses. In the booting phase, it contains by 0.7 absolute $\% \mathrm{~g}$ more than clover. Legume grasses are richer with calcium than phosphorus. In the booting phase Trifoliumrubens has calcium 8.5 times as much as phosphorus. Melilotusalbus has calcium 7.7 times as much as phosphorus. When plants get old, the levels of protein and ash decrease. However, the amount of gross energy was higher in the flowering phase due to the increase of the fiber content, of nitrogen-free extractives and dry matter in general. Due to the decrease of digestibility of the organic matter of "old" plants, the amount of metabolic energy in the dry matter of herbs in the flowering phase is less than in the early stages of vegetation.

The data on the dynamics of the NDVI over the production season in April-August, presented in accordance with areal coefficients, are of concern and presented in Figure 1.

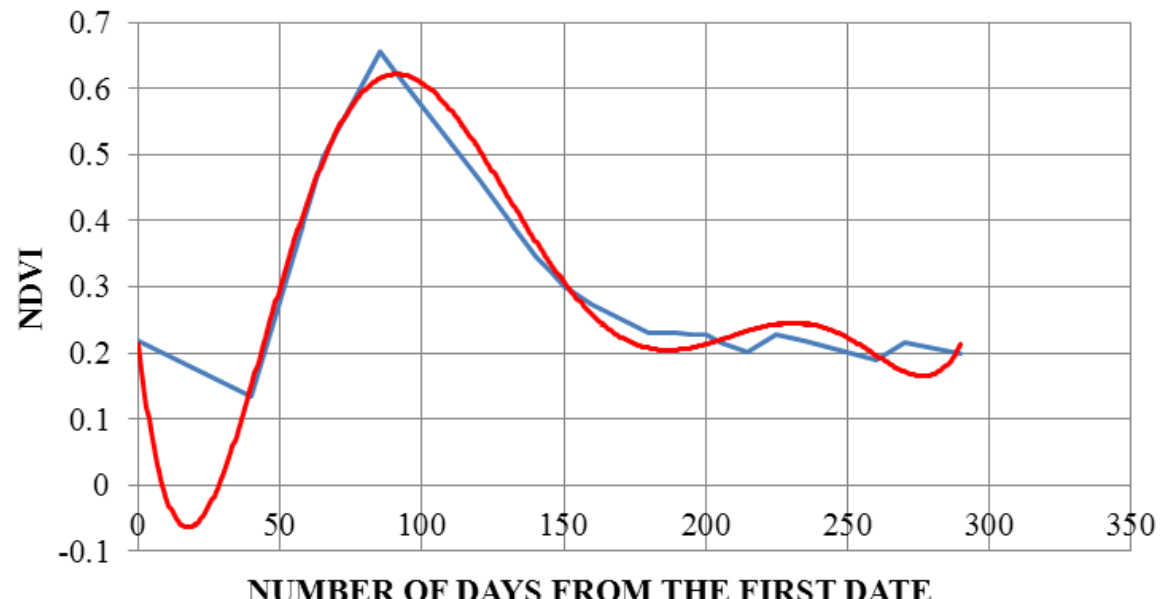

Fig. 1. Average values of NDVI in accordance withareal coefficients

Regression equation:

$$
y=3 \mathrm{E}-13 x 6-3 \mathrm{E}-10 x 5+1 \mathrm{E}-07 x 4-2 \mathrm{E}-05 x 3+0.0015 x 2-0.0365 x+0.2138,
$$

where $y$-NDVI;

$x$ - days from the first date (02.02.2018).

The range of the NDVI was from 0.133 to 0.657 . In the first quarter it changed from 0.133 to 0.217 , in the second quarter - from 0.325 to 0.657 , in the third quarter - from 0.202 to 0.301 , in the fourth quarter - from 0.19 to 0.216 . The amount of precipitation in the field is presented in Figure 2 .

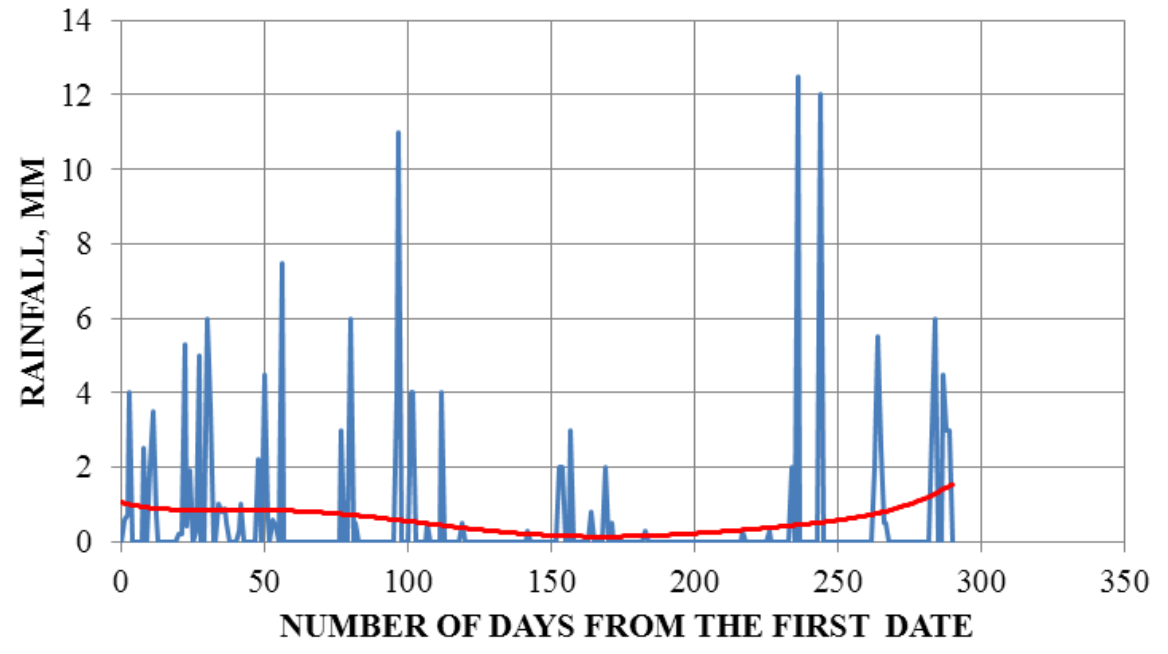

Fig. 2. Amount of precipitation on area of pasture 
Regression equation:

$$
y=3 \mathrm{E}-13 x 6-2 \mathrm{E}-10 x 5+7 \mathrm{E}-08 x 4-1 \mathrm{E}-05 x 3+0.0007 x 2-0.02 x+1.051,
$$

where $y$-NDVI;

$x$ - days from the first date (02.02.2018).

The total precipitation for the entire reference period was $163.2 \mathrm{~mm}$. It shows that the production season under study is dry.

To identify the relationship of the dynamics of the NDVI with the productive qualities of replacement young animals, a scientific and business experiment was conducted on replacement young sheep. According to the results of controlling the live weight of the tested group of 3-monthsold rams during the pasture season (April-August), as it is shown in Table 3,during the period of growing on pasture feed in a dry climate,that is shown in Figure 2, and the decrease of the quality of pasture feed due to vegetation of plants, that is shown in Table 2, there was a significant decrease of growth energy 1.7 times.

Table3

Productive qualities of replacement young animals that are 3-7months old

\begin{tabular}{|l|c|c|c|c|}
\hline \multicolumn{2}{|c|}{ Indicator } & \multicolumn{3}{c|}{ Age, months } \\
\cline { 3 - 5 } & III & V & VII \\
\hline $\begin{array}{l}\text { Average live weight for the start } \\
\text { of the experiment, kg }\end{array}$ & $M \pm m$ & $18.67 \pm 0.40$ & $29.11 \pm 0.41$ & $35.17 \pm 0.49$ \\
\hline $\begin{array}{l}\text { Daily average growth of live } \\
\text { weight, g }\end{array}$ & $M \pm m$ & - & $\begin{array}{c}173.6 \pm 2.04 \\
*\end{array}$ & $101.9 \pm 2.71$ \\
\hline
\end{tabular}

$*_{-} p<0.05$

So, at the age of 3 or 4 months experimental young sheep were grazed on pasture grasses, the NDVI of which is shown in Figure 1. The time period took 100-150 days. Herewith, the vegetation index decreased from 0.657 to 0.325 . Average daily gain of live weight of replacement young sheep was $173.6 \mathrm{~g}$ as it is shown in Table 3. Because of absence of needed precipitation in the period from the $100^{\text {th }}$ to the $230^{\text {th }}$ day in Figure 2, pasture grasses began to dry out. At the result the vegetation index began to lower till 0.202-0.301. In accordance, average daily gain of live weight of replacement young sheep lowered till $101.9 \mathrm{~g}$. So, it is $71.7 \mathrm{~g}$ less than in the prior period.

\section{Conclusions}

The results have shown that the distant monitoring of the vegetation index reflects the actual change in the quality of pasture feed and enables to predict the average daily gainoflive weight of fattening sheep. The correlation coefficient between the quality of feed in the process of vegetation and the dynamics of the vegetation index was in the range of 0.65-0.75. It gives the opportunity to use this index for prognostic purposes.

With the possibility of the combined use of distant aerospace monitoring, satellite monitoring should be used for the simultaneous assessment of large pasture plots, which take several thousand hectares. For more efficient correction of production plans and relatively small size of pastures (several hundred hectares) it is more efficient to use the UVAs of middle sizes.

\section{Acknowledgements}

The work was carried out with the financial support of the Ministry of Science and Higher Education of Russia under Agreement No. 14.613.21.0081 dated November 22, 2017. Unique identifier of works: RFMEFI61317X0081.

\section{References}

[1] Shevyrnogov A.P., ChernetskyM.Yu., Vysotskaya G.S. Perennial NDVI trends and temperatures in the south of the Krasnoyarsk Territory. Earth Study from Space, 2012, No. 6, pp. 77-87. 
[2] Shevyrnogov A.P., Vysotskaya G.S., Gitelson J.I. Quasistationary areas of chlorophyll concentration in the world ocean as observed satellite data. Advances in Space Research, 1996,volume 18, Issue 7, pp. 129-132.

[3] Hüttich C., Herold M., Schmullius C., Egorov V., Bartalev S.A. SPOT-VGT NDVI and NDWI trends 1998-2005 as indicators of recent land cover change processes in northern Eurasia. Proceedings of the 2nd Workshop of the EARSeL SIG on Land Use and Land Cover, 2006, pp. 336-344.

[4] Cleveland R.B., Cleveland W.S., McRae J.E., Terpenning I. STL: A Seasonal-Trend Decomposition Procedure Based on Loess. Journal of Official Statistics, 1990, vol. 6, pp. 3-73.

[5] Cao M., Prince S.D., Small J., Goetz S.J. Remotely sensed interannual variations and trends in terrestrial net primary productivity 1981-2000. Ecosystems, 2004,vol. 7, pp. 233-242.

[6] Ларько А.А., Иванова Ю.Д., Шевырногов А.П. Нелинейные тренды чистой первичной продукции растительности юга Красноярского края по спутниковым данным: методы и подходы // Фундаментальные исследования. 2015. № 3. С. 106-110 (Larko A.A., IvanovaYu.D., Shevyrnogov A.P. Nonlinear trends of pure primary production of vegetation in the south of the Krasnoyarsk Territory according to satellite data: methods and approaches. Fundamental Research, 2015, No. 3, pp. 106-110). (In Russian).

[7] Zhao M., Heinsch F.A., Nemani R.R., Running S.W. Improvements of the MODIS terrestrial gross and net primary production global data set. RemoteSensingofEnvironment, 2005,vol. 95, pp. 164-176.

[8] Шевырногов А. П., Ларько А. А. Квазистационарные зоны по динамике трендов NDVI мощный инструмент исследования пространственных структур растительности суши. Региональные проблемы дистанционного зондирования Земли : материалы IIIМеждунар. науч. конф. (Красноярск, 13-16 сентября 2016 г.) / науч. ред. Е. А. Ваганов ; отв. ред. М. В. Носков. Красноярск :Сиб. федер. ун-т, 2016. С. 343-345 (Shevyrnogov A.P., Larko A.A. Quasistationary zones on the dynamics of NDVI trends are a powerful tool for studying spatial structures of land vegetation. Proceedings of the III International scientific conference "On Sat Regional problems of remote sensing of the Earth" (Krasnoyarsk, September 13-16, 2016), Krasnoyarsk: Sibir Federal University, 2016, pp. 343-345).(In Russian). 